Article

\title{
Intracellular Delivery of siRNAs Targeting AKT and ERBB2 Genes Enhances Chemosensitization of Breast Cancer Cells in a Culture and Animal Model
}

\author{
Tahereh Fatemian ${ }^{1}$, Hamid Reza Moghimi ${ }^{2}$ and Ezharul Hoque Chowdhury ${ }^{1, *}$ \\ 1 Jeffry Cheah School of Medicine and Health Sciences, Monash University Malaysia, Jalan Lagoon Selatan, \\ 46150 Bandar Sunway, Malaysia \\ 2 School of Pharmacy, Shahid Beheshti University of Medical Sciences, 19839-63113 Tehran, Iran \\ * Correspondence: md.ezharul.hoque@monash.edu; Tel.: +60-3-5514-4978
}

Received: 30 June 2019; Accepted: 26 August 2019; Published: 3 September 2019

\begin{abstract}
Pharmacotherapy as the mainstay in the management of breast cancer suffers from various drawbacks, including non-targeted biodistribution, narrow therapeutic and safety windows, and also resistance to treatment. Thus, alleviation of the constraints from the pharmacodynamic and pharmacokinetic profile of classical anti-cancer drugs could lead to improvements in efficacy and patient survival in malignancies. Moreover, modifications in the genetic pathophysiology of cancer via administration of small nucleic acids might pave the way towards higher response rates to chemotherapeutics. Inorganic $\mathrm{pH}$-dependent carbonate apatite (CA) nanoparticles were utilized in this study to efficiently deliver various classes of therapeutics into cancer cells. Co-delivery of drugs and genetic materials was successfully attained through a carbonate apatite delivery device. On 4T1 cells, siRNAs against AKT and ERBB2 plus paclitaxel or docetaxel resulted in the largest increase in anti-cancer effects compared to $\mathrm{CA} /$ paclitaxel or $\mathrm{CA} /$ docetaxel. Therefore, these ingredients were selected for further in vivo investigations. Animals receiving injections of $\mathrm{CA} /$ paclitaxel or CA/docetaxel loaded with siRNAs against AKT and ERBB2 possessed significantly smaller tumors compared to $\mathrm{CA} /$ drug-treated mice. Interestingly, synergistic interactions in target protein knock down with combinations of $\mathrm{CA} / \mathrm{AKT} /$ paclitaxel, $\mathrm{CA} / \mathrm{ERBB} 2 /$ docetaxel were documented via western blotting.
\end{abstract}

Keywords: siRNA; drug delivery; nanoparticle; carbonate apatite; ERBB2; AKT; breast cancer

\section{Introduction}

Combinations of individual therapeutics indicated against malignancies might result in superior outcomes in resolving the complexity of cancer cells. Among the tackled complexities is an acquired or intrinsic resistance of the cancer cells to treatment. In fact, combining different therapeutic strategies might provide various benefits as follows: (a) Maximized therapeutic efficacy without increased overall toxicity to the host due to different mechanisms of action; (b) prevention of the development of resistance to single agents; (c) covering the heterogeneous tumor cell population with different drug sensitivity profiles; and (d) possible synergy between therapeutics, resulting in increased anticancer efficacy [1].

The underlying mechanisms of resistance might involve genetic alterations, which could be depleted via RNA interference technologies, such as small interfering RNAs (siRNAs). Phenotype modifications through suppression of mRNA transcripts by the usage of siRNA, might render the cancer cells more responsive to the accompanying chemotherapeutic agents. In the co-delivery of nucleic acids and small molecule drugs, protective vectors would assist in boosted cellular uptake, lysosomal escape, and protection against serum nucleases together with limited off-target effects. 
Nano-based formulations have the potential to be versatile and multifunctional, enabling the co-delivery of multiple agents entrapped in the nanoparticles' structure to gain synergistic anticancer effects or multi-functions.

Co-delivery of drugs and siRNAs has been documented via application of different carrier systems [2-4]. In one study, doxorubicin and Bcl-2-targeted siRNA were applied via a polyethylenimine-coated graphene oxide (PEI-GO) vehicle. Here, the GO moiety adsorbs the therapeutics while PEI enhances cell membrane penetration [2]. In another example, a triblock polymer loaded with VEGF siRNA and paclitaxel delivered augmented efficacy against paclitaxel [3]. N-succinyl chitosan-poly-L-lysine-palmitic acid (NSC-PLL-PA) has been utilized in the synthesis of a triblock copolymer for co-delivery of P-glycoprotein-targeted siRNA and doxorubicin at $\mathrm{pH}$ 7.4. These therapeutics are released upon degradation of the carrier in the acidic $\mathrm{pH}$ of lysosomes [4].

In fact, numerous examples of synthetic dual siRNA and drug-delivery vehicles have been reported in the literature, with varying formulations and results [5-8]. However, carriers consisting of protein or peptide origins have demonstrated superiority due to biodegradability, complex structure details and functional groups, feasible adjustments in the synthesis process, and also compatibility in the construction of multifunctional hybrid materials [9].

As published data demonstrate, a lipoproteoplex has been developed for the purpose of dual delivery of siRNA and doxorubicin, with the ability to condense siRNA and encapsulate the small-molecule chemotherapeutic, doxorubicin. The lipoproteoplex demonstrates improved doxorubicin loading, resulting in a substantial decrease in MCF-7 cell viability, plus effective transfection of GAPDH ( $60 \%$ knockdown) in MCF-7 breast cancer cells [9].

Inorganic carbonate apatite is a recently developed nanocarrier synthesized via calcium phosphate precipitation in the presence of bicarbonate. The controlled crystal growth dynamic leads to the formation of particles with a size ranging between 50 and $300 \mathrm{~nm}$. These carriers encompass optimal features of efficient endocytosis, fast dissolution rate in endosomal acidic $\mathrm{pH}$, and effective release of loaded therapeutics. In more detail, addition of $3 \mathrm{mM}$ of $\mathrm{Ca}$ in the synthesis of carbonate apatite results in the formation of nanoparticles with a size less than $50 \mathrm{nM}$. In presence of $10 \mathrm{nM}$ of paclitaxel, NPs reach a maximum size of around $170 \mathrm{~nm}$. Markedly, paclitaxel-loaded carbonate apatite demonstrates a $20.71 \pm 4.34 \%$ loading efficiency [10]. Carbonate apatite nanoparticles have been utilized for co-delivery of anti-cancer drugs and various siRNAs, resulting in improved outcomes [11,12].

Members of the human epidermal growth factor receptor (HER) family are among the key factors in regulating the response of breast cancer cells to chemotherapy. As another mediator in the complex pathway of oncogenesis, AKT, a serine-threonine protein kinase, has been heavily studied.

AKT signaling has been shown to be regulated by enhanced HER signals, mutational activation of Ras leading to AKT activation via the PI3K pathway, or the mutational inactivation of the PTEN phosphatase resulting in diminished AKT activity. Secondary to these alterations, AKT kinase activity would be augmented. Thereafter, increased AKT kinase activity on its own and in the absence of any upregulation in AKT protein concentrations may have a broader effect on oncogenesis as well as the cellular response to cancer therapy [13].

Thus, various components of these inter-related signaling cascades have been targeted via siRNA application in this study to obtain an accurate assessment of their role in the response of the cancer cells to chemotherapy agents.

\section{Materials and Methods}

\subsection{Materials}

Dulbecco's modified eagle medium (DMEM), calcium chloride dehydrate $\left(\mathrm{CaCl}_{2} \cdot 2 \mathrm{H}_{2} \mathrm{O}\right)$, sodium bicarbonate $\left(\mathrm{NaHCO}_{3}\right)$, dimethyl sulphoxide (DMSO), 3-(4,5-dimethylthiazol-2-yl)-2,5-diphenyl tetrazolium bromide (MTT), phosphoric acid solution $\left(\mathrm{H}_{3} \mathrm{PO}_{4}\right)$, trifluroacetice acid (TFA; $\left.\mathrm{CF}_{3} \mathrm{COOH}\right)$, Ethylene Diamine Tetraacetic Acid (EDTA), and anti-cancer drugs docetaxel (Doc) and paclitaxel (Pac) 
were purchased from Sigma-Aldrich (St Louis, MO, USA). DMEM powder, fetal bovine serum (FBS), trypsin ethylene diamine tetraacetate (trypsin-EDTA), 4-(2-hydroxyethyl)-1-piperazineethanesulfonic acid (HEPES), and penicillin-streptomycin were obtained from Gibco BRL (Carlsbad, CA, USA). All functionally validated siRNAs used in this study (listed in Table 1) were obtained from Qiagen and dissolved in RNase-free water provided by the company to obtain 10- $\mu \mathrm{M}$ stock solution. MCF-7, 4T1 and MDA-MB-231 cells were originally from ATCC.

Table 1. List of validated siRNAs (Qiagen, MD, USA) that were used in this study.

\begin{tabular}{|c|c|c|c|c|}
\hline siRNA & Target Sequence & Targeted Gene & $\begin{array}{l}\text { Validation Cell } \\
\text { Line }\end{array}$ & $\%$ knockdown \\
\hline Hs-AKT1-5 & AATCACACCACCTGACCAAGA & AKT (protein kinase B) & HeLa S3 & 90 \\
\hline Hs_MAPK1_10 & AAGTTCGAGTAGCTATCAAGA & $\begin{array}{c}\text { Mitogen-activated protein } \\
\text { kinase }\end{array}$ & HeLa S3 & 90 \\
\hline Hs-ROS1-5 & AAGGTAATTGCTCTAACTTTA & $\begin{array}{l}\text { ROS Proto-Oncogene } 1 \text {, } \\
\text { Receptor tyrosine kinase }\end{array}$ & $\mathrm{HeLa}$ & 87 \\
\hline Hs-ERBB2-14 & AACAAAGAAATCTTAGACGAA & $\begin{array}{l}\text { Receptor tyrosine-protein } \\
\text { kinase ERBB-2 } \\
\text { or human epidermal } \\
\text { growth factor receptor } 2 \\
\text { (HER2) }\end{array}$ & MCF-7 & 92 \\
\hline
\end{tabular}

\subsection{Cell Culture}

MCF-7 and MDA-MB-231 as human breast cancer cell lines and 4T1 as a mouse breast cancer cell line were cultured in $75-\mathrm{cm}^{2}$ tissue culture flasks (Nunc, Orlando, FL, USA) using DMEM supplemented with $10 \%$ FBS, $1 \%$ penicillin and streptomycin, and $1 \%$ HEPES at $37^{\circ} \mathrm{C}$ in a humidified $5 \% \mathrm{CO}_{2}$-containing atmosphere.

\subsection{Generation and Characterization of Carbonate Apatite}

Carbonate apatite nanoparticles were manufactured via addition of $\mathrm{Ca}^{2+}$ from $1 \mathrm{M} \mathrm{CaCl}_{2}$ stock solution to the bicarbonate-buffered cell culture medium (DMEM, pH adjusted to 7.5, containing $44 \mathrm{mM}$ $\left.\mathrm{HCO}^{3-}\right)$, which already contained the third reactant $(0.9 \mathrm{mM}$ phosphate), followed by incubation at $37^{\circ} \mathrm{C}$ for $30 \mathrm{~min}$. As a result, microscopically visible carbonate apatite particles were formed through precipitation following nucleation in a supersaturated solution. Turbidity determination and size and zeta potential measurement of the variously formulated nanoparticles were employed for characterization of the resulting products [10].

\subsection{Complexation of Drugs and siRNAs with Carbonate Apatite}

Various concentrations of drugs and siRNAs (Table 1) were added in DMEM media (44 mM bicarbonate, $\mathrm{pH}$ 7.5) containing particular concentrations of $\mathrm{CaCl}_{2}$ and subjected to a 30-min incubation at $37^{\circ} \mathrm{C}$ to allow formation of complexes.

\subsection{In Vitro Viability Assay}

Cytotoxicity of carbonate apatite nanoparticles alone and also differently loaded NPs on human and murine breast cancer cell lines was assessed by MTT assay. Briefly, the cells from the exponential growth phase were seeded in 24-well plates (Griener, Frickenhausen, Germany) (approximately 50,000 cells/well) in DMEM with $10 \%$ FBS at $37{ }^{\circ} \mathrm{C}$ with $5 \% \mathrm{CO}_{2}$. After $24 \mathrm{~h}$, cells were exposed to various treatments for a consecutive period of $48 \mathrm{~h}$. Two days later the viability was assessed by adding $50 \mu \mathrm{L}$ MTT solution (5 mg/mL in phosphate buffered solution (PBS)) to each well and incubating for $4 \mathrm{~h}$ in dark. Then, the medium was removed and $300 \mu \mathrm{L}$ DMSO was added to each well to dissolve the purple formazan crystals. Formazan quantification in the form of optical density (OD) was performed at test and reference wavelengths of $595 \mathrm{~nm}$ and $630 \mathrm{~nm}$ by a plate reader (benchmark plus, Bio Rad). 
Cell viability was determined using the following formula:

$$
\text { Cell viability }(\%)(\mathrm{CV})=\frac{\mathrm{OD}_{(\text {treated })}-\mathrm{OD}_{(\text {reference })}}{\mathrm{OD}_{(\text {untreated })}-\mathrm{OD}_{(\text {reference })}} \times 100 \text {. }
$$

The reference was the optical density of DMSO only in the applied wavelengths.

Each experiment was done in triplicate and results are expressed as mean \pm SD of $\%$ of cell viability. Subsequently, an increase in cytotoxic effect of the loaded NPs was calculated as follows:

$$
\text { Increase in toxicity }(\%)=\mathrm{CV}_{\text {baseline treatment }}-\mathrm{CV}_{\text {complete treatment, }}
$$

where $\mathrm{CV}_{\text {baseline treatment }}$ and $\mathrm{CV}$ complete treatment represent the cell viability resulting from the baseline treatment and complete treatment, respectively. In all bar charts (Supplementary Figures) displaying cell viability values, each two adjacent bars were compared together and an increase in toxicity was calculated for all different concentrations and expressed as mean \pm SD.

\subsection{Sodium Dodecyl Sulfate Polyacrylamide Gel Electrophoresis (Sds-Page) and Western Blot}

Treated cells in each well of a 24-well plate were lysed by addition of $200 \mu \mathrm{L}$ of whole cell IP-lysis buffer and protein sample was collected. Then, $5 \mu \mathrm{L}$ solution was used for estimation of total protein content using the BSA assay kit according to instruction provided by the manufacturer (Quick-start Bradford protein assay kit, Bio Rad, Hercules, CA, USA).

Samples of the cell lysate containing equal amounts of total protein (e.g., $10 \mu \mathrm{g}$ ) were mixed with $10 \mu \mathrm{L}$ of $10 \times$ loading dye and heated for $5 \mathrm{~min}$ at $95{ }^{\circ} \mathrm{C}$ and then resolved by SDS-PAGE using stain free mini protean SFX gels (10 wells) in $1 X$ running buffer. In total, $7 \mu \mathrm{L}$ of precision plus protein standards-dual color were used as a molecular weight marker to confirm the molecular weight of the proteins in the samples. The protein samples were transferred from gel to the $0.2-\mu \mathrm{m}$ polyvinylidene difluoride (PVDF) membranes and attached using a trans-blot turbo transfer system (Bio Rad). Membranes were blocked in 5\% skimmed milk in 1X TBST for an hour at room temperature.

The membrane was probed with indicated primary antibody (Table 2) overnight at $4{ }^{\circ} \mathrm{C}$. Unbound primary antibodies were washed using $1 X$ TBST buffer for 5 times, 5 min each, with gentle agitation. Blots were probed with horseradish peroxide conjugated secondary antibody (anti-rabbit IgG, 1:3000) for $1 \mathrm{~h}$ at room temperature. TBST was again used to remove excess secondary antibody by 5 wash cycles each $5 \mathrm{~min}$ long with gentle agitation. Clarity Western Enhanced Chemiluminescence (ECL) substrate (Bio-Rad) was applied onto the membrane in the dark for $5 \mathrm{~min}$ and the signals on the membrane were visualized via a Bio-Rad Gel documentation system.

\begin{tabular}{|c|c|c|c|c|}
\hline Name & Manufacturer & Molecular Weight & Clonality & Used Dilution \\
\hline $\begin{array}{c}\text { AKT (pan) (C67E7) Rabbit } \\
\text { mAb }\end{array}$ & $\begin{array}{l}\text { Cell signaling (Danvers, } \\
\text { MA, USA) }\end{array}$ & $60 \mathrm{KDa}$ & Monoclonal & $1: 1000$ \\
\hline $\begin{array}{l}\text { p 44/42 MAPK (Erk 1/2) } \\
\text { (137F5) Rabbit mAb }\end{array}$ & $\begin{array}{l}\text { Cell signaling (Danvers, } \\
\text { MA, USA) }\end{array}$ & $42 / 44 \mathrm{KDa}$ & Monoclonal & $1: 1000$ \\
\hline ERBB2 (HER2) & $\begin{array}{l}\text { Thermo Fisher scientific } \\
\text { (Waltham, MA, USA) }\end{array}$ & $200 \mathrm{KDa}$ & Polyclonal & $1: 1000$ \\
\hline $\begin{array}{c}\text { GAPDH } \\
\text { (glyceraldehyde-3-phosphate } \\
\text { dehydrogenase) }\end{array}$ & $\begin{array}{c}\text { Cell signaling (Danvers, } \\
\text { MA, USA) }\end{array}$ & $37 \mathrm{KDa}$ & Monoclonal & $1: 3000$ \\
\hline
\end{tabular}

Table 2. Information for the primary antibodies used for western blot in this study.

\subsection{Formulation of Particles for In Vivo Study}

The injectable nanoparticles were formulated in $100 \mu \mathrm{L}$ of freshly prepared bicarbonated $(44 \mathrm{mM})$ DMEM media to which $\mathrm{CaCl}_{2}$ was added. Samples were then incubated at $37^{\circ} \mathrm{C}$ for $30 \mathrm{~min}$ followed 
by maintenance on ice to prevent aggregation during injection. In drugcontaining samples, $1.25 \mathrm{mg} / \mathrm{kg}$ of Pac and $1 \mathrm{mg} / \mathrm{kg}$ of Doc were used prior to incubation. In case of using siRNAs, $50 \mathrm{nM}$ of each siRNA was added to the media prior to incubation. The resulting therapeutics were used for iv treatment of animals.

\subsection{T1-Induced Breast Cancer Murine Model}

Female Balb/c mice with the age of 6 to 8 weeks and body weight of 15 to $20 \mathrm{~g}$ were used in this study.

Animals were maintained in a 12:12 light:dark condition and provided with food ab libitum and water. All experiments were performed in complete adherence to the regulations of Monash University Animal Welfare Committee. The details of the animal study were approved by Monash Animal Ethics Committee on 3 August 2012 with the project identification code of MARP/2012/087 under the title of "Delivery of anti-cancer drugs to breast cancer cells using nanoparticles". Tumor induction was performed via subcutaneous injection of 4 T1 cells (in $100 \mu \mathrm{L}$ PBS) on the mammary fat pad of mice. Injection day was considered as day 1 of the animal study. The development of tumor was regularly assessed through manual examination of the injection site. Randomization and treatment were carried out when the volume of the tumor reached an average of $13.20 \pm 2.51 \mathrm{~mm}^{3}$ (Table 3). Treatment was administered via intravenous injection through the right or left caudal vein. Duration of study was 30 days, which involved close monitoring of the animals together with recording their body weights and tumor outgrowth every other day. The following formula was used for calculation of the tumor volume:

$$
\text { Tumor volume }\left(\mathrm{mm}^{3}\right)=\frac{\left(\text { Length } \times \text { Width }^{2}\right)}{2}
$$

Table 3. Treatment groups used for in vivo study.

\begin{tabular}{|c|c|}
\hline Group & Regimen \\
\hline Untreated & - \\
\hline CA & $7 \mu \mathrm{L}$ of $1 \mathrm{M} \mathrm{CaCl}_{2}$ in DMEM \\
\hline CA & $4 \mu \mathrm{L}$ of $1 \mathrm{M} \mathrm{CaCl}_{2}$ in DMEM \\
\hline Pac & $1.25 \mathrm{mg} / \mathrm{kg}$ paclitaxel in DMEM \\
\hline Doc & $1 \mathrm{mg} / \mathrm{kg}$ docetaxel in DMEM \\
\hline $\mathrm{CA} / \mathrm{Pac}$ & $1.25 \mathrm{mg} / \mathrm{kg}$ paclitaxel and $7 \mu \mathrm{L}$ of $1 \mathrm{M} \mathrm{CaCl}_{2}$ in DMEM \\
\hline $\mathrm{CA} / \mathrm{Pac}$ & $1.25 \mathrm{mg} / \mathrm{kg}$ paclitaxel and $4 \mu \mathrm{L}$ of $1 \mathrm{M} \mathrm{CaCl}_{2}$ in DMEM \\
\hline CA/Doc & $1 \mathrm{mg} / \mathrm{kg}$ docetaxel and $4 \mu \mathrm{L}$ of $1 \mathrm{M} \mathrm{CaCl}_{2}$ in DMEM \\
\hline CA/AKT & $50 \mathrm{nM}$ of AKT siRNA and $4 \mu \mathrm{L}$ of $1 \mathrm{M} \mathrm{CaCl}_{2}$ in DMEM \\
\hline CA/ERBB2 & $50 \mathrm{nM}$ of ERBB2 siRNA and $4 \mu \mathrm{L}$ of $1 \mathrm{M} \mathrm{CaCl}_{2}$ in DMEM \\
\hline CA/AKT/ERBB2/Pac & $\begin{array}{l}1.25 \mathrm{mg} / \mathrm{kg} \text { paclitaxel and } 50 \mathrm{nM} \text { of ERBB2 and AKT siRNA and } 4 \mu \mathrm{L} \text { of } \\
\qquad 1 \mathrm{M} \mathrm{CaCl}_{2} \text { in DMEM }\end{array}$ \\
\hline CA/AKT/ERBB2/Doc & $\begin{array}{l}1 \mathrm{mg} / \mathrm{kg} \text { docetaxel and } 50 \mathrm{nM} \text { of ERBB2 and AKT siRNA and } 4 \mu \mathrm{L} \text { of } 1 \mathrm{M} \\
\qquad \mathrm{CaCl}_{2} \text { in DMEM }\end{array}$ \\
\hline
\end{tabular}

\subsection{Statistics}

For determining statistical significance of quantifications, student's $t$-test was used; all data are presented as mean \pm SD. Data was considered significant for $p$ values $<0.05$.

\section{Results and Discussion}

\subsection{Cytotoxicity of siRNA-Loaded NPs on MCF-7 and $4 T 1$ Cells}

To explore the efficacy of carbonate apatite in the delivery of siRNAs into the cells and also evaluate the effect of single gene knock down on the viability of cancer cells, carbonate apatite nanoparticles 
harboring single siRNA were tested on MCF-7 and $4 \mathrm{~T} 1$ cells. Here, $4 \mathrm{mM}$ of $\mathrm{CaCl}_{2}$ was applied in the presence of various amounts of single siRNAs to produce treatment formulations.

Binding of siRNA to NPs, in the presence of increasing concentrations of calcium and fixed siRNA amounts, is saturable and reaches a plateau level, in spite of the escalating pattern of particle size. Higher amounts of calcium together with limited endogenous phosphate $(0.9 \mathrm{mM})$ accounts for an increased particle size due to aggregation and not larger individual particles. Limited surface area of the particles secondary to aggregation results in restricted siRNA binding [14].

Remarkably, CA capacity in the efficient delivery of siRNAs into their action site is displayed by the considerable enhancement in the cytotoxic effects for almost all amounts of siRNAs complexed with CA compared to free siRNA. The most killing effect on MCF-7 and 4T1 seems to be achieved by muting the HER2 or ROS1 cascade (Table 4) (Supplementary Figures S1 and S2), indicating the strong impact of ERBB2 or ROS signaling on the survival of both cell lines.

Table 4. Cytotoxicity (\%) enhancement on $4 \mathrm{~T} 1$ and MCF-7 cells treated with various siRNAs (1 pM, $10 \mathrm{pM}, 100 \mathrm{pM}, 1 \mathrm{nM}$, and $10 \mathrm{nM}$ ) incorporated into an apatite structure formed with $3 \mathrm{mM}$ of $\mathrm{CaCl}_{2}$. The data is presented as mean \pm SD compared to free siRNA.

\begin{tabular}{ccccccc}
\hline \multirow{2}{*}{ Cell line } & \multirow{2}{*}{ Treatment } & \multicolumn{5}{c}{ siRNA Concentration } \\
\cline { 3 - 7 } & & $\mathbf{1} \mathbf{~ p M}$ & $\mathbf{1 0} \mathbf{~} \mathbf{M}$ & $\mathbf{1 0 0} \mathbf{~ M M}$ & $\mathbf{1} \mathbf{~ n M}$ & $\mathbf{1 0} \mathbf{~ M}$ \\
\hline \multirow{3}{*}{$4 \mathrm{~T} 1$} & CA/ERBB2 & $16.44 \pm 5.77$ & $33.24 \pm 9.14$ & $26.70 \pm 3.93$ & $28.09 \pm 6.28$ & $19.80 \pm 1.13$ \\
& CA/AKT & $14.11 \pm 5.41$ & $-4.58 \pm 5.01$ & $3.42 \pm 1.23$ & $-3.27 \pm 4.48$ & $-3.96 \pm 2.98$ \\
& CA/MAPK & $10.68 \pm 3.69$ & $-0.72 \pm 0.87$ & $17.59 \pm 1.04$ & $5.36 \pm 1.15$ & $25.45 \pm 4.64$ \\
& CA/ROS1 & $13.85 \pm 6.99$ & $14.68 \pm 3.87$ & $27.46 \pm 1.17$ & $16.65 \pm 1.44$ & $35.56 \pm 2.81$ \\
\hline \multirow{2}{*}{ MCF-7 } & CA/ERBB2 & $07.49 \pm 8.01$ & $24.56 \pm 3.19$ & $13.82 \pm 3.34$ & $19.29 \pm 3.91$ & $8.63 \pm 1.67$ \\
& CA/ROS1 & $12.52 \pm 2.79$ & $13.69 \pm 3.07$ & $23.97 \pm 2.13$ & $28.88 \pm 2.29$ & $29.70 \pm 3.96$ \\
\hline
\end{tabular}

In another research, carbonate apatite nanoparticles have been confirmed as efficient carriers for electrostatically associated siRNA inside the cells, releasing bound siRNA from endosomes to the cytosol through $\mathrm{pH}$-responsive self-dissolution. This was concluded based on the significant increase in the fluorescence intensity of the intracellular components from the cells treated with $\mathrm{CA} /$ fluorescent siRNA compared to untreated and CA-treated cells [14].

Moreover, application of different concentrations of 'Allstars Negative Control siRNA' (1 pM to $10 \mathrm{nM}$ ) loaded into a carbonate apatite structure resulted in no alteration of breast cancer cells' viability [11].

However, the duration of response of the cancer cells to single-oncogene inhibitors, even the most potent oncogenes, is mostly short due to the development of resistance or upregulation of compensatory mechanisms in survival and proliferation signaling. Therefore, sustained and significant outcomes are mainly achieved with combinations of various classes of anti-cancer therapies. In case of no initial response to treatment or development of drug resistance, combinatory regimens are of great benefit to induce therapeutic response. In fact, putting off the causal cascades of resistance by one agent might result in re-sensitization of the cells to other therapeutics in the combination.

Markedly, pharmacokinetics and pharmacodynamics interactions between the agents in combination therapy might develop in case of a shared action site, uptake, and metabolism or elimination routes.

Delivery of drugs and siRNAs by means of carbonate apatite nanoparticles into cells was further studied. The aim was to evaluate the impact of silencing different signaling pathways on the response of cancer cells to the cytotoxic effects of drugs. Different concentrations of paclitaxel, docetaxel, mitomycin C, and topotecan $(10 \mathrm{pM}, 100 \mathrm{pM}$, and $1 \mathrm{nM})$ were used together with $1 \mathrm{pM}$ of siRNAs against AKT, ERBB2, MAPK, and ROS1 and $3 \mathrm{mM} \mathrm{Ca}$. Based on extensive experiments and with the aim of exploring possible synergistic effects, the lowest effective doses of therapeutics were applied. This was to perhaps achieve a therapeutic effect with lower doses and hence less side effects. 
Notably, application of anti HER2 siRNA together with any of the four drugs caused positive changes in cytotoxicity against 4T1 cells (Supplementary Figures S3-S6). Additionally, co-delivery of Pac and ROS1 siRNA or Doc and MAPK siRNA seemed to sensitize 4T1 cells to the drug to a great extent.

Response of MDA-MB-231 cells to chemotherapy in case of single pathway silencing was also explored. Paclitaxel and docetaxel were used in complexes of carbonate apatite using $3 \mathrm{mMCa}$ and $10 \mathrm{pM}$, $100 \mathrm{pM}$, and $1 \mathrm{nM}$ of the drug together with $1 \mathrm{nM}$ of each siRNA. As the cell viability data reveals, Pac efficacy benefits from silencing ERBB2 or ROS1 pathways in terms of a highest increase in cytotoxicity on MDA-MB-231 cells (Supplementary Figure S7). Whereas, AKT or ERBB2 pathways display a significant role in response to docetaxel in MDA-MB-231 cells, as with knock down of these two oncogenes, all concentrations of Doc exert a substantial higher cytotoxicity (Supplementary Figure S8).

As the next step, simultaneous silencing of AKT and ERBB2 oncogenes was implemented to check if these pathways have any impact on the response to classical anti-cancer drugs.

Carbonate apatite was formed with $3 \mathrm{mM}$ of $\mathrm{CaCl}_{2}$ and $1 \mathrm{pM}$ of AKT and ERBB2 siRNA together with $10 \mathrm{pM}, 100 \mathrm{pM}$, and $1 \mathrm{nM}$ of paclitaxel, docetaxel, mitomycin C, and topotecan. Based on cell viability results (Supplementary Figure S9), knock down of AKT and ERBB2 seems to have the greatest impact on the response to paclitaxel or docetaxel in $4 \mathrm{~T} 1$ cells. The highest enhancement in cytotoxicity on $4 \mathrm{~T} 1$ is equal to $19.97 \pm 1.73 \%$ for Pac and $15.16 \pm 3.55 \%$ for Doc, resulting from simultaneous blockade of AKT and ERBB2 signaling. Thus, these combinations were applied for in vivo studies since the animal tumor model was developed by local injection of $4 \mathrm{~T} 1$ cells in mice.

On MDA-MB-231 cells, application of siRNAs for simultaneous silencing of two pathways led to augmented cytotoxicity of paclitaxel as well. This effect was higher with usage of AKT and ROS1 siRNA or co-delivery of AKT and MAPK siRNAs in the presence of Pac (Supplementary Figure S10).

Tables 5-7 demonstrate the enhancement of the cytotoxic effect of classical anti-cancer drugs resulting from the silencing of various pathways in MCF-7, 4T1, and MDA-MB-231 cells, respectively.

Table 5. Effect of silencing various pathways on cytotoxicity of classical anti-cancer drugs in MCF-7 cells. Data is presented as mean $\pm \mathrm{SD}$ compared to $\mathrm{CA} /$ drug.

\begin{tabular}{cccc}
\hline \multirow{2}{*}{ Treatment on MCF-7 Cells } & \multicolumn{3}{c}{ Drug Concentration } \\
\cline { 2 - 4 } & $\mathbf{1 0} \mathbf{~} \mathbf{M}$ & $\mathbf{1 0 0} \mathbf{~} \mathbf{M}$ & $\mathbf{1} \mathbf{~ n M}$ \\
\hline CA/Pac/AKT & $10.93 \pm 1.05$ & $8.33 \pm 0.84$ & $3.31 \pm 0.45$ \\
CA/Pac/ERBB2 & $7.25 \pm 1.91$ & $4.11 \pm 0.35$ & $3.40 \pm 1.81$ \\
CA/Pac/MAPK & $-10.79 \pm 2.12$ & $1.53 \pm 0.55$ & $2.06 \pm 0.35$ \\
CA/Pac/ROS1 & $4.19 \pm 1.41$ & $3.14 \pm 0.74$ & $3.64 \pm 0.19$ \\
CA/Doc/AKT & $5.14 \pm 1.22$ & $10.45 \pm 1.33$ & $11.69 \pm 2.18$ \\
CA/Doc/ERBB2 & $8.95 \pm 2.28$ & $10.25 \pm 0.99$ & $14.28 \pm 1.04$ \\
CA/Doc/MAPK & $3.22 \pm 0.91$ & $4.27 \pm 0.08$ & $3.67 \pm 1.72$ \\
CA/Doc/ROS1 & $1.06 \pm 0.59$ & $2.83 \pm 0.71$ & $1.25 \pm 0.53$ \\
\hline
\end{tabular}

Table 6. Effect of silencing various pathways on cytotoxicity of classical anti-cancer drugs in $4 \mathrm{~T} 1$ cells. Data is presented as mean $\pm \mathrm{SD}$ compared to CA/drug.

\begin{tabular}{cccc}
\hline \multirow{2}{*}{ Treatment on 4T1 Cells } & \multicolumn{3}{c}{ Drug Concentration } \\
\cline { 2 - 4 } & $\mathbf{1 0} \mathbf{~} \mathbf{M}$ & $\mathbf{1 0 0} \mathbf{~ p M}$ & $\mathbf{1 ~ n M}$ \\
\hline CA/Pac/AKT & $-15.93 \pm 0.95$ & $8.70 \pm 2.14$ & $-2.68 \pm 0.54$ \\
CA/Pac/ERBB2 & $12.93 \pm 0.36$ & $9.15 \pm 0.14$ & $2.42 \pm 2.84$ \\
CA/Pac/MAPK & $-13.79 \pm 1.18$ & $2.53 \pm 0.20$ & $2.16 \pm 0.11$ \\
CA/Pac/ROS1 & $10.09 \pm 1.03$ & $2.04 \pm 0.85$ & $7.24 \pm 0.07$ \\
CA/Doc/AKT & $-5.04 \pm 0.77$ & $-9.43 \pm 0.51$ & $1.30 \pm 0.62$ \\
CA/Doc/ERBB2 & $5.85 \pm 1.08$ & $7.21 \pm 1.17$ & $2.20 \pm 1.95$ \\
CA/Doc/MAPK & $3.16 \pm 0.21$ & $5.07 \pm 0.98$ & $2.67 \pm 0.76$ \\
CA/Doc/ROS1 & $2.76 \pm 0.58$ & $1.81 \pm 0.97$ & $0.05 \pm 0.42$ \\
\hline
\end{tabular}


Table 6. Cont.

\begin{tabular}{cccc}
\hline \multirow{2}{*}{ Treatment on 4T1 Cells } & \multicolumn{3}{c}{ Drug Concentration } \\
\cline { 2 - 4 } & $\mathbf{1 0} \mathbf{~ p M}$ & $\mathbf{1 0 0} \mathbf{~} \mathbf{M}$ & $\mathbf{1} \mathbf{~} \mathbf{M}$ \\
\hline CA/Mito/AKT & $0.20 \pm 0.71$ & $4.97 \pm 1.15$ & $1.92 \pm 0.28$ \\
CA/Mito/ERBB2 & $2.13 \pm 3.64$ & $5.11 \pm 0.85$ & $1.71 \pm 0.38$ \\
CA/Mito/MAPK & $1.26 \pm 1.23$ & $0.23 \pm 1.45$ & $7.77 \pm 0.95$ \\
CA/Mito/ROS1 & $0.72 \pm 0.92$ & $0.52 \pm 0.16$ & $4.20 \pm 1.12$ \\
CA/Topo/AKT & $0.02 \pm 1.64$ & $3.09 \pm 0.42$ & $5.28 \pm 3.07$ \\
CA/Topo/ERBB2 & $4.54 \pm 2.27$ & $5.85 \pm 0.47$ & $0.86 \pm 2.51$ \\
CA/Topo/MAPK & $6.54 \pm 0.55$ & $0.55 \pm 0.51$ & $4.74 \pm 0.88$ \\
CA/Topo/ROS1 & $0.58 \pm 0.25$ & $0.03 \pm 0.36$ & $0.52 \pm 0.81$ \\
CA/Pac/AKT/ERBB2 & $19.97 \pm 1.73$ & $5.48 \pm 2.09$ & $11.63 \pm 2.23$ \\
CA/Doc/AKT/ERBB2 & $7.87 \pm 1.82$ & $1.45 \pm 0.37$ & $15.16 \pm 3.55$ \\
CA/Mito/AKT/ERBB2 & $6.04 \pm 0.28$ & $0.59 \pm 0.47$ & $4.60 \pm 0.82$ \\
CA/Topo/AKT/ERBB2 & $-10.41 \pm 0.66$ & $-4.73 \pm 1.52$ & $-10.77 \pm 0.71$ \\
\hline
\end{tabular}

Table 7. Effect of silencing various pathways on cytotoxicity of classical anti-cancer drugs in MDA-MB-231 cells. Data is presented as mean \pm SD compared to CA/drug.

\begin{tabular}{cccc}
\hline \multirow{2}{*}{ Treatment on MDA-MB-231 Cells } & \multicolumn{3}{c}{ Drug Concentration } \\
\cline { 2 - 4 } & $\mathbf{1 0} \mathbf{~} \mathbf{M}$ & $\mathbf{1 0 0} \mathbf{~} \mathbf{M}$ & $\mathbf{1} \mathbf{~ n M}$ \\
\hline CA/Pac/AKT & $4.60 \pm 1.53$ & $-8.84 \pm 0.92$ & $7.55 \pm 1.43$ \\
CA/Pac/ERBB2 & $12.03 \pm 2.44$ & $0.59 \pm 1.32$ & $12.03 \pm 3.57$ \\
CA/Pac/MAPK & $8.96 \pm 2.16$ & $0.35 \pm 0.36$ & $8.25 \pm 1.28$ \\
CA/Pac/ROS1 & $11.08 \pm 2.09$ & $0.35 \pm 0.09$ & $7.90 \pm 1.83$ \\
CA/Doc/AKT & $3.66 \pm 0.24$ & $8.97 \pm 2.94$ & $16.16 \pm 4.52$ \\
CA/Doc/ERBB2 & $20.05 \pm 4.61$ & $7.97 \pm 3.06$ & $8.02 \pm 1.49$ \\
CA/Doc/MAPK & $-1.06 \pm 0.58$ & $6.14 \pm 2.73$ & $6.49 \pm 1.91$ \\
CA/Doc/ROS1 & $0.59 \pm 0.34$ & $10.74 \pm 3.16$ & $7.90 \pm 1.52$ \\
CA/Pac/AKT/ERBB2 & $7.07 \pm 2.22$ & $3.71 \pm 0.85$ & $13.29 \pm 1.12$ \\
CA/Pac/AKT/MAPK & $18.62 \pm 3.64$ & $14.42 \pm 2.14$ & $3.37 \pm 3.47$ \\
CA/Pac/AKT/ROS1 & $11.26 \pm 1.05$ & $-0.12 \pm 0.93$ & $22.40 \pm 3.44$ \\
CA/Pac/ERBB2/MAPK & $1.32 \pm 0.07$ & $-1.44 \pm 0.12$ & $12.22 \pm 2.33$ \\
CA/Pac/ERBB2/ROS1 & $-0.48 \pm 0.52$ & $-9.70 \pm 0.49$ & $5.51 \pm 1.86$ \\
CA/Pac/MAPK/ROS1 & $9.58 \pm 1.24$ & $-4.79 \pm 0.93$ & $6.23 \pm 2.22$ \\
\hline
\end{tabular}

According to the cell viability data displayed in Table 5, silencing AKT or ERBB2 regulates the response of MCF-7 cells to paclitaxel or docetaxel substantially. Thus, the effect of these therapeutic agents on the protein expression was further evaluated via Western blotting.

Induction of cell death followed by application of therapeutically loaded carbonate apatite could be associated with involvement of the apoptotic pathway, based on escalation of caspase-7-mediated signaling [12].

Silencing of AKT or HER2 signaling to expedite treatment outcomes in cancer is backed up by a solid body of knowledge. Expression of HER2 in MCF7 cells has been shown to increase under certain conditions $[15,16]$.

According to recent research, docetaxel induces either apoptosis accompanied by survivin upregulation or necrosis and a lower rate of survivin upregulation in various breast cancer cell lines, based on cells receptor expression profile and the molecular phenotype. Additionally, inhibition of p-AKT was shown to revert survivin upregulation and also induce docetaxel-dependent apoptosis [17].

In another study, inhibition of NRF2 in ERBB2-overexpressing ovarian carcinoma cells was shown to suppress ERBB2 expression, which led to a decrease in phospho-AKT and enhanced p27 protein together with increased sensitivity of these cells to docetaxel cytotoxicity and apoptosis [18]. 
There are also other published data associating increased paclitaxel-induced apoptosis with inhibition of AKT in ovarian cancer cells. While paclitaxel-resistant cells demonstrated higher levels of p-AKT compared to paclitaxel-sensitive cells, inhibition of AKT increased paclitaxel therapeutic efficacy in both cell lines [19].

Moreover, combination of shRNA against AKT1 with paclitaxel exerted synergistic anti-cancer effects, thus inhibiting the growth of human breast cancer MDA-MB-231 and MCF-7 cells, and breast cancer MDA-MB-231 cell xenografts in mice as well. The combination therapy demonstrated enhanced anti-cancer effects through inhibition of AKT1 signaling and induction of apoptosis [20].

Extensive in vitro and in vivo research has associated ERBB2 overexpression with resistance of breast cancer cells to certain chemotherapeutic agents, namely docetaxel and paclitaxel. Furthermore, in clinical studies, herceptin, the anti-ERBB2 antibody, enhanced the antitumor activity of paclitaxel and doxorubicin against ERBB2-overexpressing human breast cancer xenografts, and the paclitaxel response rate of patients with ERBB2-overexpressing breast cancers was significantly higher among patients receiving paclitaxel plus herceptin than those receiving paclitaxel alone [21]. Additionally, co-administration of a PI3K inhibitor with cytotoxic or targeted anticancer agents, such as carboplatin, paclitaxel, or erlotinib, led to increased tumor growth inhibition over the corresponding single agents [22].

Moreover, high AKT activity has been shown to be responsible for the enhanced resistance of ERBB2-overexpressing cancer cells toward chemotherapeutic agents, and inhibition of AKT activation by peptide aptamer resulted in the restoration of regular sensitivity of breast cancer MCF7 cells towards paclitaxel [23].

In another research, siRNA-based knockdown of HER-2 conferred increased sensitivity to paclitaxel in endometrial cancer cells, attenuating the induction of p-AKT on paclitaxel stimulation, which was cancelled by inactivating AKT by the introduction of a dominant-negative form [24].

\subsection{Effect of CA/siRNA/Drug at the Protein Level}

As cell viability assays revealed, silencing AKT or ERBB2 exerts the maximum effect on the enhancement of cytotoxicity of Pac or Doc on MCF-7. Thus, the underlying mechanism of reduced viability following administration of these treatments was investigated via western blotting. This was performed to confirm that the applied siRNA is effective in the knock down of the target protein synthesis and also to observe the changes in protein expression leading to enhanced chemo sensitivity.

AKT expression following treatment of MCF-7 cells with free AKT siRNA and CA-complexed AKT siRNA was assessed and compared with untreated cells. As the bands on the blot and densitometry analysis reveal (Figure 1), complexation of siRNA with carbonate apatite leads to significantly decreased expression of AKT compared to free AKT siRNA and untreated cells ( $p$ value $<0.05$ ). This confirms the efficacy of CA in the successful delivery of siRNA and knock down of the target protein.

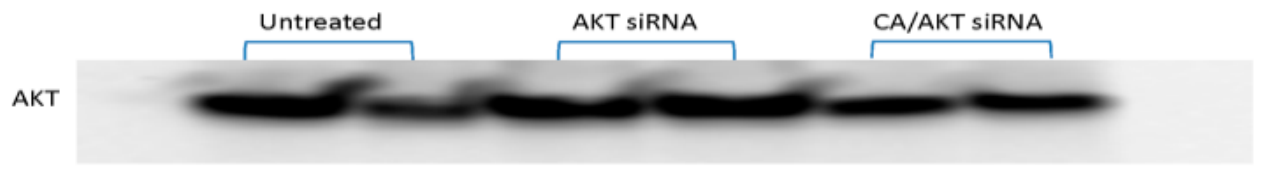

Figure 1. AKT protein expression in MCF-7 cells. Cells were treated with media (untreated), free AKT siRNA, and CA/AKT siRNA formed with $3 \mathrm{mM}$ of $\mathrm{CaCl}_{2}$ and $1 \mathrm{nM}$ siRNA for $44 \mathrm{~h}$. Cellular lysates were resolved by SDS-PAGE and transferred in PVDF membrane followed by incubation with primary antibodies raised in rabbit against AKT. HRP-conjugated goat anti-rabbit secondary antibody was used to detect the chemiluminescent signals.

The same experiment design was utilized with MAPK siRNA. According to Figure 2, free MAPK siRNA does not change the expression level of MAPK protein whereas CA/MAPK significantly knocks down production of the target protein $(p$ value $<0.05)$. 


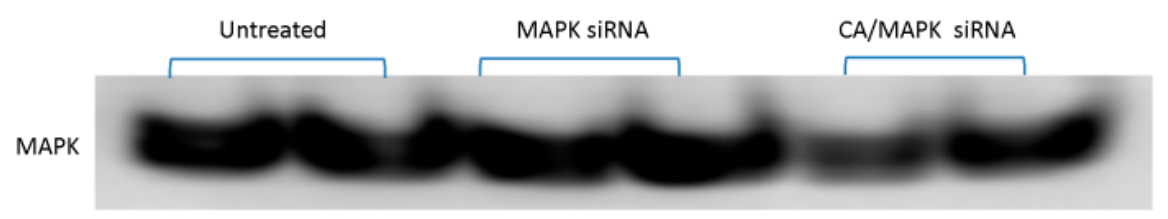

Figure 2. MAPK protein expression in MCF-7 cells. Cells were treated with media (untreated), free MAPK siRNA, and CA/MAPK siRNA formed with $3 \mathrm{mM}$ of $\mathrm{CaCl}_{2}$ and $1 \mathrm{nM}$ siRNA for $44 \mathrm{~h}$. Cellular lysates were resolved by SDS-PAGE and transferred into PVDF membrane followed by incubation with primary antibodies raised in rabbit against AKT. HRP-conjugated goat anti-rabbit secondary antibody was used to detect the chemiluminescent signals.

Next, changes in protein expression resulting from the combinations of drugs and siRNAs, as highlighted in the cell viability data, were studied. MCF-7 cell lysate treated with free and CA-bound AKT siRNA, CA/AKT/Pac and CA/Pac were loaded on the gels. According to the resulting bands (Figure 3), the lowest level of AKT protein was obtained by CA/AKT/Pac treatment versus CA/Pac or CA/AKT. This implies the development of synergistic interactions to suppress survival pathways in the presence of classical anti-cancer drugs together with genetic downregulation of survival proteins, which in turn might lead to enhanced sensitivity of the cells to the anti-cancer medication.

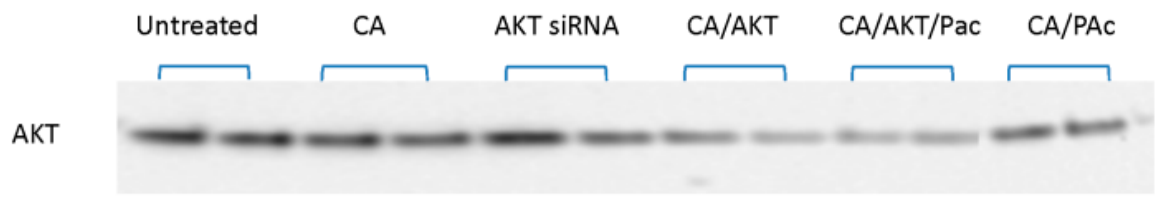

Figure 3. AKT protein expression in MCF-7 cells. Cells were treated with media (untreated), carbonate apatite, free AKT siRNA, CA/AKT siRNA, CA/AKT/Pac, and CA/Pac. Ingredients include $3 \mathrm{mM}$ of $\mathrm{CaCl}_{2}, 1 \mathrm{nM}$ siRNA, and $1 \mathrm{nM}$ Pac. Cellular lysates were run in SDS-PAGE and transferred into PVDF membrane and incubated with primary antibodies raised in rabbit against AKT. HRP-conjugated goat anti-rabbit secondary antibody was used to detect the chemiluminescent signals.

The same synergistic pattern, but with a lower potency, was observed with application of $\mathrm{CA} / \mathrm{AKT} / \mathrm{Doc}$ in the downregulation of AKT protein against CA/AKT or CA/Doc (Figure 4).

$\begin{array}{llllllll} & \text { Untreated } & \text { CA } & \text { AKT } & \text { CA/AKT } & \text { CA/AKT/Doc } & \text { CA/Doc } \\ \text { AKT } & & & & & & & \\ & & & & & & & \end{array}$

Figure 4. AKT protein expression in MCF-7 cells. Cells were treated with media (untreated), carbonate apatite, free AKT siRNA, CA/AKT siRNA, CA/AKT/Doc, and CA/Doc. Ingredients include $3 \mathrm{mM}$ of $\mathrm{CaCl}_{2}, 1 \mathrm{nM}$ siRNA, and $1 \mathrm{nM}$ Doc. Cellular lysates were run in SDS-PAGE and transferred into PVDF membrane and incubated with primary antibodies raised in rabbit against AKT. HRP-conjugated goat anti-rabbit secondary antibody was used to detect the chemiluminescent signals.

Based on a substantial enhancement in efficacy, the impact of different combinations of ERBB2 siRNA with paclitaxel or docetaxel on the expression level of ERBB2 protein was also examined. As the blot in Figure 5 shows, the highest knock down was achieved by co-delivery of CA-bound Doc and ERBB2 siRNA followed by CA/Pac/ERBB2. Again, the synergy in the therapeutic efficacy of the drug together with siRNA is present since the impact of the drug or siRNA as a single agent is considerably weaker. 


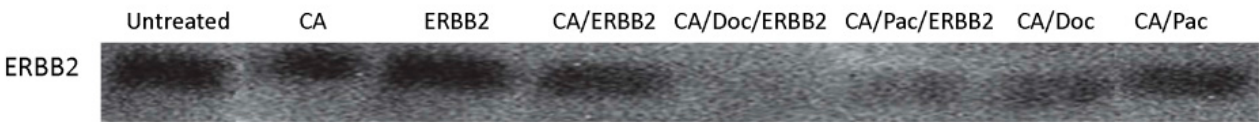

Figure 5. ERBB2 protein expression in MCF-7 cells. Cells were treated with media (untreated), carbonate apatite, free ERBB2 siRNA, CA/ERBB2 siRNA, CA/Doc/ERBB2, CA/Pac/ERBB2, CA/Doc, and $\mathrm{CA} /$ Pac. Ingredients include $3 \mathrm{mM}$ of $\mathrm{CaCl}_{2}, 1 \mathrm{nM}$ siRNA, and $1 \mathrm{nM}$ drug. Cellular lysates were run in SDS-PAGE and transferred into PVDF membrane and incubated with primary antibodies raised in rabbit against ERBB2. HRP-conjugated goat anti-rabbit secondary antibody was used to detect the chemiluminescent signals.

\subsection{In Vivo Efficacy of CA/Drug/siRNA}

According to cell viability data on $4 \mathrm{~T} 1$ cells and the enhancement in the cytotoxicity of drugs, co-delivery of AKT and ERBB2 siRNAs together with Pac or Doc resulted in the highest increase in the drug's efficacy. Thus, these two combinations were applied in animal study.

For comparison of the in vivo efficacy of the therapeutics in the first batch, animals were treated on day 8 and 11. Formulations were prepared by mixing $4 \mathrm{mM} \mathrm{Ca}, 1.25 \mathrm{mg} / \mathrm{kg}$ Pac, $50 \mathrm{nM}$ AKT siRNA plus $50 \mathrm{nM}$ ERBB2 siRNA in $100 \mu \mathrm{L}$ of $\mathrm{HCO}_{3}$-DMEM. There were no significant changes in the pattern of body weight change and also general signs and symptoms of the animals among different groups of the studies.

As the t-test results reveal, CA-AKT-ERBB2-Pac treatment significantly reduced the tumor volume on day 14 and 16 compared to $\mathrm{Ca} / \mathrm{Pac}$. Moreover, the group treated with CA/ERBB2 displayed significantly smaller tumors compared to the CA group on day 12 and 14 . The effect of Pac complexed with CA on tumor regression was significant on day 14 versus free paclitaxel therapy (Figure 6).

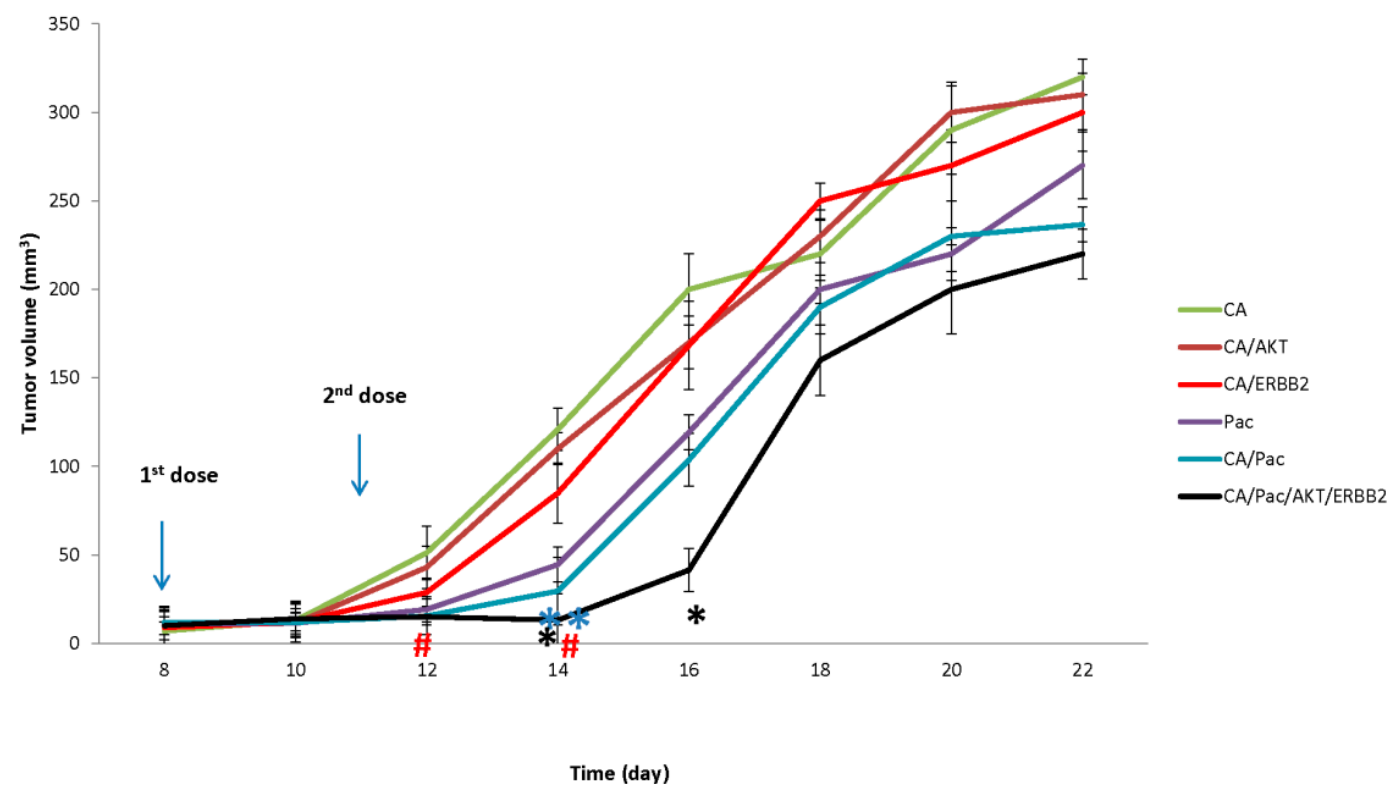

Figure 6. Effect of silencing AKT and ERBB2 pathways on in vivo efficacy of paclitaxel. Mice were purchased from Razi Research Institute, Tehran, Iran. Approximately $10^{6} 4 \mathrm{~T} 1$ cells were inoculated subcutaneously on the mammary pad of mice. Based on tumor volume calculations, mice were randomized and treated intravenously through tail-vein injection on day 8 and 11. The therapeutics included $100 \mu \mathrm{L}$ of carbonate apatite entailing $4 \mu \mathrm{L}$ of $1 \mathrm{M} \mathrm{CaCl}_{2}$ and $50 \mathrm{nM}$ of AKT and ERBB2 siRNA plus $1.25 \mathrm{mg} / \mathrm{kg}$ Pac. Body weight and tumor outgrowth were monitored every other day. Data is represented as mean $\pm \mathrm{SD}, n=6$ and values are significant when $* p$ value $<0.05$ for CA/Pac/AKT/ERBB2 vs. $\mathrm{CA} / \mathrm{Pac}, \# p$ value $<0.05$ for $\mathrm{CA} / \mathrm{ERBB} 2$ compared to $\mathrm{CA}$ and ${ }^{* *} p$ value $<0.05$ for $\mathrm{CA} / \mathrm{Pac}$ against Pac. 
In another batch, injections on day 10 and 13 encompassed preparations of $4 \mathrm{mM} \mathrm{Ca}, 1 \mathrm{mg} / \mathrm{kg}$ Doc, $50 \mathrm{nM}$ AKT siRNA, and $50 \mathrm{nM}$ ERBB2 siRNA in $100 \mu \mathrm{L}$ bicarbonated DMEM (Figure 7).

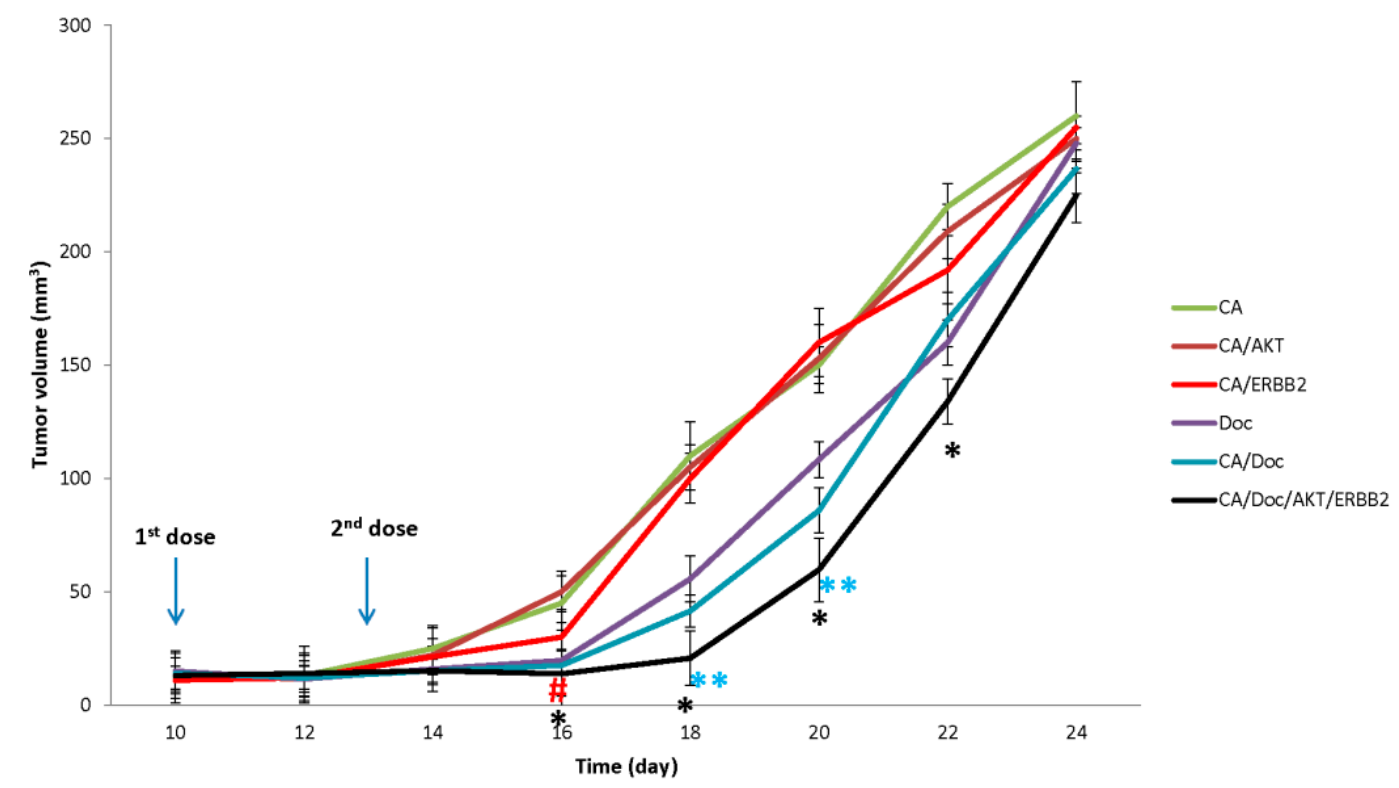

Figure 7. Effect of silencing AKT and ERBB2 pathways on in vivo efficacy of docetaxel. Mice were purchased from Razi Research Institute, Tehran, Iran. Approximately $10^{6} 4 \mathrm{~T} 1$ cells were inoculated subcutaneously on the mammary pad of mice. Based on tumor volume calculations, mice were randomized and treated intravenously through tail-vein injection on day 10 and 13 . The therapeutics included $100 \mu \mathrm{L}$ of carbonate apatite entailing $4 \mu \mathrm{L}$ of $1 \mathrm{M} \mathrm{CaCl}_{2}$ and $50 \mathrm{nM}$ of AKT and ERBB2 siRNA plus $1 \mathrm{mg} / \mathrm{kg}$ Doc. Body weight and tumor outgrowth were monitored every other day. Data is represented as mean $\pm \mathrm{SD}, n=6$ and values are significant when ${ }^{*} p$ value $<0.05$ for CA/Doc/AKT/ERBB2 vs CA/Doc, $\# p$ value $<0.05$ for CA/ERBB2 compared to CA and ${ }^{* *} p$ value $<0.05$ for Ca/Doc against Doc.

According to the $p$ values calculated in the $\mathrm{t}$-test, treatment of animals with CA/Doc/AKT/ERBB2 resulted in significantly smaller tumor volumes on days 16, 18, 20, and 22 compared to CA/Doc. Whereas CA/ERBB2 displayed a significant anti-tumor efficacy only on day 16 compared to CA, and $\mathrm{CA} / \mathrm{AKT}$ was not effective in tumor regression. Animals treated with $\mathrm{CA} / \mathrm{Doc}$ had significantly smaller tumors on day 18 and 20 compared to Doc-treated animals.

ERBB2 overexpression has been linked to elevated levels of inhibitory phosphorylation of Cdc2 and suppression of paclitaxel-induced cell death in breast cancer cells via deregulation of the G2/M cell cycle checkpoint. This provides a mechanistic rationale for the association between ERBB2 overexpression and paclitaxel resistance. Interestingly, overexpression of a subunit of PI3k in ovarian cancer cells has been shown to confer paclitaxel resistance. Additionally, selective inhibition of the PI3k pathway could restore the efficacy of paclitaxel in those cells [25]. Thus, alterations in the expression and activity levels of key components of these signaling networks regulating cellular proliferation and survival may confer paclitaxel resistance. Further, circumvention of this type of resistance might be achieved via application of selective inhibitors of these proteins to increase drug sensitivity.

Simultaneous targeting of AKT and ERBB2 to achieve improvements in eradication of oncogenesis has been brought up in various studies.

Overexpression or activation of HER members and also AKT has been linked to limited benefits of treatment in patients, leading to poor prognosis in breast cancer. In fact, functionally relevant alterations in AKT1 could be a putative mediator of tumor progression and drug resistance. Moreover, amplification or gain-of-function mutations of ERBB2 can account for hyperactivation of the AKT cascade in breast cancer cells. Crosstalk with heterologous receptors and amplification of HER2 signaling, amplifications of the PI3K/AKT pathway, and de-repression and/or activation of compensatory survival pathways 
through increased PI3K/AKT signaling are among the resistance mechanisms against anti-HER2 therapy. Factors associated with resistance to ERBB2-targeted agents have been invariably associated with a reactivation of the PI3K/AKT signaling cascade [26,27]. However, defects in HER2/PI3K/AKT axes and their impact on regulation of the response of cancer cells to treatment need further investigation.

In an experimental design, HER2-positive MCF7 cells showed a PI3K-dependent increase in AKT activity together with increased resistance to a panel of five chemotherapeutic agents with known different mechanisms of action (paclitaxel, doxorubicin, 5-fluorouracil, etoposide, and camptothecin). Selective inhibition of PI3K or AKT in these HER2-overexpressing MCF7 cells reduced the levels of phosphorylated (activated) AKT and sensitized the cells to the chemotherapeutic agents. It has been further confirmed that expression of a constitutively active AKT vector alone in MCF7 cells caused similarly increased resistance of the cells to the chemotherapeutic agents [13]. Therefore, the HER2/PI3K/AKT pathway is confirmed to play a causal role in the resistance of breast cancer cells against several therapeutics, and targeting components of this pathway might resolve the resistance and enhance the efficacy of the treatments. In view of that, the in vitro and in vivo results of this study are in alignment with the documented role of AKT and ERBB2 in drug resistance.

Strikingly, the efficacy of simultaneous knock down of AKT and ERBB2 in augmenting the response of cancer cells to docetaxel was reported for the first time in this study.

Markedly, the strategic location of AKT and its activation by multiple upstream signal transduction pathways makes it a better target than its upstream targets, such as HER2, Ras, or PI3K, in sensitizing cancer cells to chemotherapy or radiotherapy. Thus, there could be clinical benefits from an appropriate combination of conventional chemotherapeutic drugs with a new generation of signal transduction inhibitors that inhibit the HER/PI3K/AKT pathway for the treatment of breast cancer.

A summary of the ERBB2 and AKT signaling cascades regulating cell's proliferation, survival, and resistance to apoptosis and treatment is illustrated in Figure 8. This is for clarification of the enhanced efficacy of Pac or Doc attained by simultaneous blockade of AKT and ERBb2 cascades and the impact on the response of the cells to the drugs.

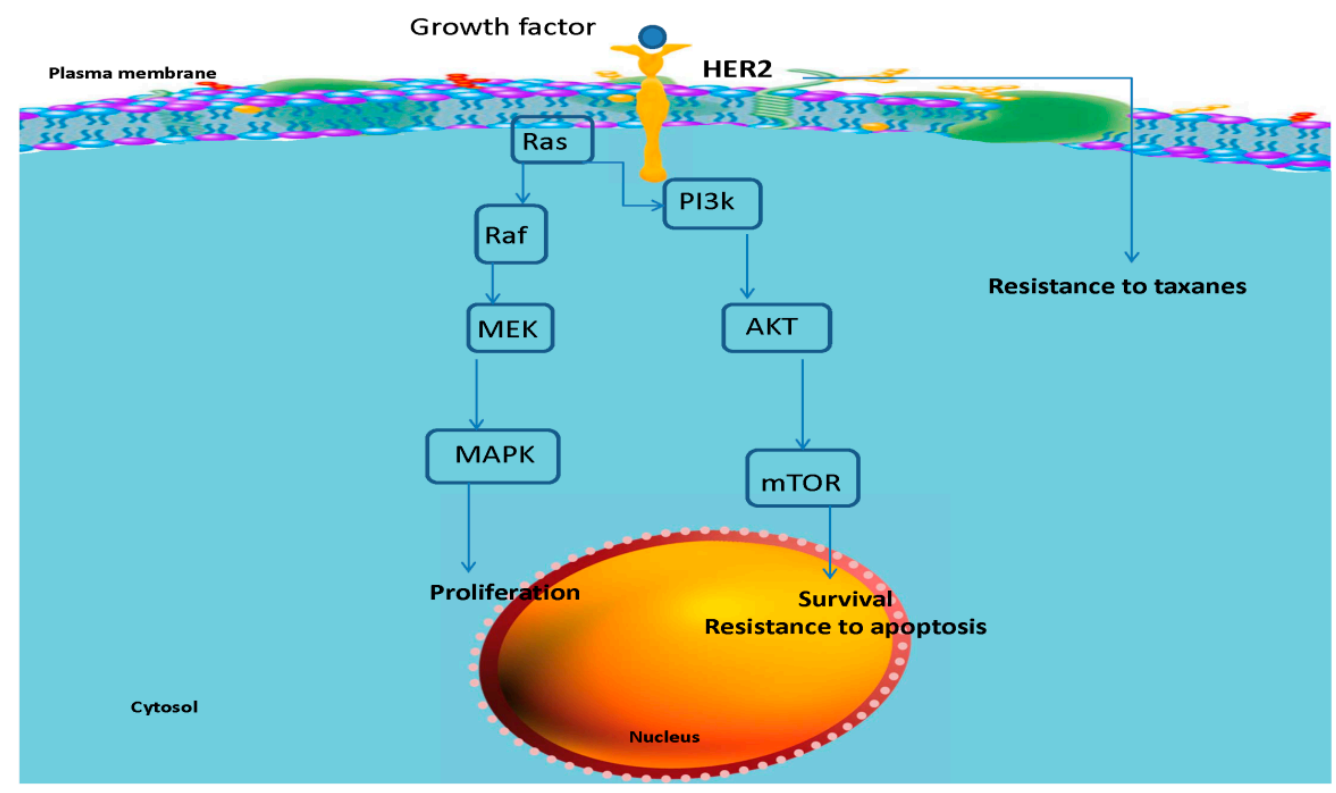

Figure 8. Summary of the ERBB2 and AKT signaling cascades regulating the cell's proliferation, survival, and resistance to apoptosis and treatment.

As revealed through the extensive experiments on breast cancer cells and animal models plus protein expression studies, simultaneous knock down of AKT1 and ERBB2 expression in the presence of paclitaxel or docetaxel leads to a substantial increase in cellular response to the chemotherapeutic 
agent both in culture and an animal model. Synergistic interactions in target protein knock down have been documented via western blotting in the cells treated with these combinations, which would shed light on the underlying mechanisms of the enhanced sensitivity of the cells to treatment. Taken together, with a favorable in vitro profile and also superior in vivo efficacy, co-administration of genetic materials and classical chemotherapeutics could propose a promising platform for improved strategies against cancer cells in upcoming practice.

Supplementary Materials: The following are available online at http://www.mdpi.com/1999-4923/11/9/458/s1, Figure S1. Cell viability assessment in $4 \mathrm{~T} 1$ cells treated with siRNA loaded carbonate apatite. Figure S2. Carbonate apatite facilitated delivery of ERBB2 (A) and ROS1 (B) siRNA to MCF-7 cells. Figure S3. Effect of single pathway silencing on cytotoxicity of paclitaxel on 4T1 cells. Figure S4. Effect of single pathway silencing on cytotoxicity of docetaxel on 4T1 cells. Figure S5. Effect of single pathway silencing on cytotoxicity of mitomycin C on 4T1 cells. Figure S6. Effect of single pathway silencing on cytotoxicity of topotecan on 4T1 cells. Figure S7. Effects of single pathway silencing on paclitaxel cytotoxicity in MDA-MB-231. Figure S8. Effects of single pathway silencing on docetaxel cytotoxicity. Figure S9. Effects of silencing AKT and ERBB2 oncogenes on drugs cytotoxicity in 4 T1. Figure S10. Cell viability assay on MDA-MB-231 cells treated with carbonate apatite complexed with paclitaxel and two siRNAs.

Author Contributions: T.F. carried out experiments and data analysis under the supervision of H.R.M. and E.H.C., H.R.M. provided resources while E.H.C. originally designed the project and provided the resources.

Funding: This research was supported by MOSTI Science fund (Project ID: 02-02-10-SF0299) of Malaysia.

Conflicts of Interest: The authors declare no conflict of interest.

\section{References}

1. Holohan, C.; Van Schaeybroeck, S.; Longley, D.B.; Johnston, P.G. Cancer drug resistance: An evolving paradigm. Nat. Rev. Cancer 2013, 13, 714-726. [CrossRef] [PubMed]

2. Zhang, L.; Lu, Z.; Zhao, Q.; Huang, J.; Shen, H.; Zhang, Z. Enhanced Chemotherapy Efficacy by Sequential Delivery of siRNA and Anticancer Drugs Using PEI-Grafted Graphene Oxide. Small 2011, 7, 460-464. [CrossRef] [PubMed]

3. Zhu, C.; Jung, S.; Luo, S.; Meng, F.; Zhu, X.; Park, T.G.; Zhong, Z. Co-delivery of siRNA and paclitaxel into cancer cells by biodegradable cationic micelles based on PDMAEMA-PCL-PDMAEMA triblock copolymers. Biomaterials 2010, 31, 2408-2416. [CrossRef] [PubMed]

4. Zhang, C.; Zhu, W.; Liu, Y.; Yuan, Z.; Yang, S.; Chen, W.; Li, J.; Zhou, X.; Liu, C.; Zhang, X. Novel polymer micelle mediated co-delivery of doxorubicin and P-glycoprotein siRNA for reversal of multidrug resistance and synergistic tumor therapy. Sci. Rep. 2016, 6, 23859. [CrossRef] [PubMed]

5. Meng, H.; Liong, M.; Xia, T.; Li, Z.; Ji, Z.; Zink, J.I.; Nel, A.E. Engineered Design of Mesoporous Silica Nanoparticles to Deliver Doxorubicin and P-Glycoprotein siRNA to Overcome Drug Resistance in a Cancer Cell Line. Am. Chem. Soc. Nano 2010, 4, 4539-4550. [CrossRef] [PubMed]

6. Taratula, O.; Kuzmov, A.; Shah, M.A.; Garbuzenko, O.B.; Minko, T. Nanostructured lipid carriers as multifunctional nanomedicine platform for pulmonary co-delivery of anticancer drugs and siRNA. J. Control. Release 2013, 171, 349-357. [CrossRef]

7. Meng, H.; Mai, W.X.; Zhang, H.; Xue, M.; Xia, T.; Lin, S.; Wang, X.; Zhao, Y.; Ji, Z.; Zink, J.I.; et al. Codelivery of an Optimal Drug/siRNA Combination Using Mesoporous Silica Nanoparticles to Overcome Drug Resistance in Breast Cancer in Vitro and in Vivo. Am. Chem. Soc. Nano 2013, 7, 994-1005. [CrossRef]

8. Elzoghby, A.O.; Samy, W.M.; Elgindy, N.A. Protein-based nanocarriers as promising drug and gene delivery systems. J. Control. Release 2012, 161, 38-49. [CrossRef]

9. Liu, C.F.; Chen, R.; Frezzo, J.A.; Katyal, P.; Hill, L.K.; Yin, L.; Srivastava, N.; More, H.T.; Renfrew, P.D.; Bonneau, R.; et al. Efficient Dual siRNA and Drug Delivery Using Engineered Lipoproteoplexes. Biomacromolecules 2017, 18, 2688-2698. [CrossRef]

10. Fatemian, T.; Chowdhury, E.H. Cytotoxicity Enhancement in Breast Cancer Cells with Carbonate Apatite-Facilitated Intracellular Delivery of Anti-Cancer Drugs. Toxics 2018, 6, E12. [CrossRef]

11. Tiash, S.; Chua, M.J.; Chowdhury, E.H. Knockdown of ROS1 gene sensitizes breast tumor growth to doxorubicin in a syngeneic mouse model. Int. J. Oncol. 2016, 48, 2359-2366. [CrossRef] [PubMed] 
12. Tiash, S.; Chowdhury, E.H. siRNAs targeting multidrug transporter genes sensitize breast tumor to doxorubicin in a syngeneic mouse model. J. Drug Target. 2018, 27, 325-337. [CrossRef] [PubMed]

13. Knuefermann, C.; Lu, Y.; Liu, B.; Jin, W.; Liang, K.; Wu, L.; Schmidt, M.; Mills, G.B.; Mendelsohn, J.; Fan, Z. HER2/PI-3K/Akt activation leads to a multidrug resistance in human breast adenocarcinoma cells. Oncogene 2003, 22, 3205-3212. [CrossRef] [PubMed]

14. Tiash, S.; Kamaruzman, N.I.B.; Chowdhury, E.H. Carbonate apatite nanoparticles carry siRNA(s) targeting growth factor receptor genes, EGFR1 and ERBB2 to regress mouse breast tumor. Drug Deliv. 2017, 24, 1721-1730. [CrossRef] [PubMed]

15. Knowlden, J.M.; Hutcheson, I.R.; Jones, H.E.; Madden, T.; Gee, J.M.; Harper, M.E.; Barrow, D.; Wakeling, A.E.; Nicholson, R.I. Elevated levels of epidermal growth factor receptor/c-erbB2 heterodimers mediate an autocrine growth regulatory pathway in tamoxifen-resistant MCF-7 cells. Endocrinology 2003, 144, 1032-1044. [CrossRef]

16. Kumar, R.; Mandal, M.; Lipton, A.; Harvey, H.; Thompson, C.B. Overexpression of HER2 modulates bcl-2, bcl-XL, and tamoxifen-induced apoptosis in human MCF-7 breast cancer cells. Clin. Cancer Res. 1996, 2 , 1215-1219.

17. De Iuliis, F.; Salerno, G.; Giuffrida, A.; Milana, B.; Taglieri, L.; Rubinacci, G.; Giantulli, S.; Terella, F.; Silvestri, I.; Scarpa, S. Breast cancer cells respond differently to docetaxel depending on their phenotype and on survivin upregulation. Tumor Biol. 2016, 37, 2603-2611. [CrossRef]

18. Manandhar, S.; Choi, B.H.; Jung, K.A.; Ryoo, I.G.; Song, M.; Kang, S.J.; Choi, H.G.; Kim, J.A.; Park, P.H.; Kwak, M.K. NRF2 inhibition represses ErbB2 signaling in ovarian carcinoma cells: Implications for tumor growth retardation and docetaxel sensitivity. Free Radic. Biol. Med. 2012, 52, 1773-1785. [CrossRef]

19. Kim, S.H.; Juhnn, Y.S.; Song, Y.S. Akt Involvement in Paclitaxel Chemoresistance of Human Ovarian Cancer Cells. Ann. N. Y. Acad. Sci. 2007, 1095, 82-89. [CrossRef]

20. Guo, D.D.; Hong, S.H.; Jiang, H.L.; Kim, J.H.; Minai-Tehrani, A.; Kim, J.E.; Shin, J.Y.; Jiang, T.; Kim, Y.K.; Choi, Y.J.; et al. Synergistic effects of Akt1 shRNA and paclitaxel-incorporated conjugated linoleic acid-coupled poloxamer thermosensitive hydrogel on breast cancer. Biomaterials 2012, 33, 2272-2281. [CrossRef]

21. Hung, D.Y.; Chie, M. Overexpression of ErbB2 in cancer and ErbB2-targeting strategies. Oncogene 2000, 19, 6115-6121.

22. Echeverria, C.G.; Sellers, W.R. Drug discovery approaches targeting the PI3K/Akt pathway in cancer. Oncogene 2008, 27, 5511-5526. [CrossRef] [PubMed]

23. Kunz, C.; Borghouts, C.; Buerger, C.; Groner, B. Peptide Aptamers with Binding Specificity for the Intracellular Domain of the ErbB2 Receptor Interfere with AKT Signaling and Sensitize Breast Cancer Cells to Taxol. Mol. Cancer Res. 2006, 4, 983-998. [CrossRef] [PubMed]

24. Mori, N.; Kyo, S.; Nakamura, M.; Hashimoto, M.; Maida, Y.; Mizumoto, Y.; Takakura, M.; Ohno, S.; Kiyono, T.; Inoue, M. Expression of HER-2 affects patient survival and paclitaxel sensitivity in endometrial cancer. Br. J. Cancer 2010, 103, 889-898. [CrossRef] [PubMed]

25. Orr, G.A.; Verdier-Pinard, P.; McDaid,H.; Horwitz, S.B. Mechanisms of Taxol resistance related to microtubules. Oncogene 2003, 22, 7280-7295. [CrossRef] [PubMed]

26. Zhao, Y.H.; Liu, H.; Liu, Z.; Ding, Y.; Ledoux, S.P.; Wilson, G.L.; Voellmy, R.; Lin, Y.; Lin, W.; Nahta, R.; et al. Overcoming trastuzumab resistance in breast cancer by targeting dysregulated glucose metabolism. Cancer Res. 2011, 71, 4585-4597. [CrossRef]

27. Shattuck, D.L.; Miller, J.K.; Carraway, K.L.; Sweeney, C. Met receptor contributes to trastuzumab resistance of Her2-overexpressing breast cancer cells. Cancer Res. 2008, 68, 1471-1477. [CrossRef]

(C) 2019 by the authors. Licensee MDPI, Basel, Switzerland. This article is an open access article distributed under the terms and conditions of the Creative Commons Attribution (CC BY) license (http://creativecommons.org/licenses/by/4.0/). 